\title{
Clostridium difficile Toxin A Stimulates Intracellular Calcium Release and Chemotactic Response in Human Granulocytes
}

\author{
Charalabos Pothoulakis," Richard Sullivan," David A. Melnick, George Triadafilopoulos," \\ Anne-Sophie Gadenne, ${ }^{\ddagger}$ Tova Meshulam, and J. Thomas LaMont* \\ Sections of Gastroenterology, ${ }^{*}$ Hematology, ${ }^{\ddagger}$ and Infectious Diseases, Evans Memorial Department \\ of Clinical Research, University Hospital, Boston, Massachusetts 02118
}

\begin{abstract}
Clostridium difficile, a common enteric pathogen, mediates tissue damage and intestinal fluid secretion by release of two protein exotoxins: toxin $A$, an enterotoxin, and toxin $B$, a cytotoxin. Because toxin $A$ elicits an intense inflammatory reaction in vivo, we studied the effects of highly purified $C$. difficile toxins on activation of human granulocytes. Toxin $A$ at concentrations of $10^{-7}$ to $10^{-6} \mathrm{M}$, but not toxin $\mathrm{B}$, elicited a signifcant chemotactic and chemokinetic response by granulocytes that was comparable with that induced by the chemotactic factor $N$-FMLP $\left(10^{-7} \mathrm{M}\right)$. Neither toxin stimulated release of superoxide anion from granulocytes. Toxin $A$ produced a rapid, transient rise in cytosolic $\left[\mathrm{Ca}^{2+}\right]_{i}$, as measured by quin 2 fluorescence. Pertussis toxin and depletion of intra- and extracellular calcium blocked the toxin $A$ effect on cytosolic $\left[\mathrm{Ca}^{2+}\right]_{i}$. These findings suggest that the inflammatory effects of $C$. difficile toxin $A$ in the intestine may be related to its ability to mobilize intracellular $\mathrm{Ca}^{2+}$ and elicit a chemotactic response by granulocytes.
\end{abstract}

\section{Introduction}

Clostridium difficile, the causative agent of antibiotic-associated colitis, produces an enterotoxin, toxin A, and a cytotoxin, toxin B. Toxin A produces secretion of fluid in ligated rabbit ileal loops, and also elicits an acute inflammatory response in the mucosa characterized by granulocyte infiltration, epithelial cell necrosis and ulceration, and hemorrhagic edema $(1,2)$. In contrast, purified toxin B does not cause fluid secretion, inflammatory infiltrate, or morphologic damage in rabbit or hamster intestine (1-3). The effects of toxin A are not accompanied by elevation of adenylate cyclase (4), indicating that its mechanism of action differs from cholera toxin and Escherichia coli heat labile enterotoxin, which stimulate intestinal adenylate cyclase and cause fluid secretion without producing an inflammatory infiltrate $(5,6)$.

Granulocytes are activated by various chemotactic factors to migrate to sites of tissue injury and release inflammatory mediators. Chemotactic factors bind to membrane receptors on granulocytes, eliciting a wide range of responses including membrane depolarization (7), release of intracellular calcium

Address correspondence to Dr. LaMont, University Hospital, 75 E. Newton St., Boston, MA 02118.

Received for publication 7 April 1987 and in revised form 22 October 1987.

J. Clin. Invest.

(c) The American Society for Clinical Investigation, Inc.

$0021-9738 / 88 / 06 / 1741 / 05 \$ 2.00$

Volume 81, June 1988, 1741-1745
(8), inositol phospholipid turnover (9), and protein phosphorylation (10). These signals in turn activate a full range of granulocyte responses including chemotaxis, degranulation, and oxygen radical production. To further elucidate the mechanisms of the intestinal inflammatory response in $C$. difficile colitis, we studied the effects of purified toxins $A$ and $B$ on migration, superoxide anion production, and cytosolic calcium concentration in human granulocytes.

\section{Methods}

Toxin purification. Toxins A and B were prepared from culture supernatants of $C$. difficile strain 10463 . Toxin B was purified by sequential ion-exchange chromatography as described previously by us (11). Purified toxin B migrated in SDS-PAGE as a $150-\mathrm{kD}$ protein under nonreducing conditions and as a $50-\mathrm{kD}$ protein under reducing conditions. Toxin B cytotoxicity was assayed by rounding of IMR-90 fibroblasts (Institute of Medical Research, Camden, NJ) as previously described (12) and expressed as the highest 10-fold dilution causing rounding after 24-h exposure. Typical preparations of toxin B used in these studies contained between 250 and $1,000 \mu \mathrm{g} / \mathrm{ml}$ protein as measured by BioRad assay (13) and were cytotoxic at $10^{-6}$ to $10^{-8}$ dilution. Toxin A was purified to homogeneity by the method of Sullivan et al. (14). Purified toxin A migrated in SDS-PAGE as a 229-kD band. Toxin A purification was monitored by cell rounding of IMR-90 fibroblasts and enterotoxicity was assayed in rabbit ileal loops (15).

Granulocyte chemotaxis. Human granulocytes were prepared from 100-200-ml samples of heparinized blood as described previously (16). Viability was $>99 \%$ as assessed by trypan blue exclusion. More than $99 \%$ of cells were granulocytes as determined by 500 -cell differential counts. Chemotaxis (directed migration) of granulocytes was performed in a multiwell chemotaxis assembly (Neuro Probe, Bethesda, MD) as described previously by us (17). Random migration was defined as the distance migrated in microns towards buffer without added chemoattractant, while directed migration was distance migrated toward a chemoattractant. To differentiate between chemokinetic (increased random migration) and chemotactic (increased directed migration) effects of toxin $A$, we performed a checkerboard analysis as originally described by Zigmond and Hirsch (18). In these experiments, varied concentrations of toxin A were added to both upper (granulocytes) and lower (chemoattractant) wells to alter the gradient across the filter.

Superoxide anion production. Superoxide anion production was measured as the superoxide dismutase-inhibitable reduction of ferricytochrome $c$ by the method of Babior et al. (19). Triplicate samples of $2 \times 10^{6}$ granulocytes were suspended in HBSS containing ferricytochrome $c$ (final concentration, $60 \mu \mathrm{M})$. Superoxide dismutase $(100$ $\mu \mathrm{g} / \mathrm{ml}$ ) was added to one tube of each triplicate set. After warming to $37^{\circ} \mathrm{C}$, the stimulus was added to bring the total volume of the reaction mixture to $1 \mathrm{ml}$. In another series of experiments granulocytes were incubated with $5 \mu \mathrm{g} / \mathrm{ml}$ of cytochalasin B for $5 \mathrm{~min}$ at $37^{\circ} \mathrm{C}$ and then were exposed to the stimulus. The samples were then incubated for 15 $\min$ at $37^{\circ} \mathrm{C}$ with gentle agitation. The reactions were halted by rapid centrifugation, and the amount of reduced indicator in the supernatant was quantitated by its absorption peak at $551 \mathrm{~nm}$. Nonspecific reduc- 
tion of ferricytochrome $c$ in control tubes containing superoxide dismutase was subtracted from all data.

Free intracellular calcium. Fluctuations of intracellular calcium concentration were quantitated with the fluorescent probe quin 2 as described previously by us (20). In some experiments the fluorescent probe Indo-1/acetoxymethyl ester (Molecular Probes Inc., Junction City, OR) was used to determine changes in intracellular $\mathrm{Ca}^{2+}$ according to the technique of Lazzari et al. (21). In some experiments, quin 2-loaded granulocytes $\left(5 \times 10^{6} / \mathrm{ml}\right)$ prepared as described above were incubated with $500 \mathrm{ng} / \mathrm{ml}$ of pertussis toxin (List Biochemical Laboratories Inc., Campbell, CA) for $90 \mathrm{~min}$ at $37^{\circ} \mathrm{C}$. After incubation, changes in $\left[\mathrm{Ca}^{2+}\right]_{i}$ after the addition of toxin A, FMLP, or the antineutrophil monoclonal antibody PMN 7C3 (17) were monitored.

In most experiments, granulocytes were preloaded with quin 2 in HBSS containing a calcium concentration of $1.6 \mathrm{nM}$. By extrapolation from fluorescence measurements the cells were estimated to have a resting free cytosolic calcium concentration of $110 \pm 9 \mathrm{nM}$ (mean \pm SEM). A population of granulocytes that had been depleted of intracellular calcium were prepared by preloading the cells with quin 2 in calcium-free buffer containing $1 \mathrm{mM}$ EGTA. Under these conditions, extracellular calcium is not available to replace intracellular calcium that is chelated by quin 2 (22). In these preparations of cells, we observed that the intracellular content of quin 2 was the same as that of cells preloaded in HBSS which contained calcium, but that the resting concentration of free calcium was reduced to $16 \pm 3 \mathrm{nM}$ (mean \pm SEM). A total of four separate experiments were performed using three different preparations of purified toxin $A$.

To estimate as to whether toxin A has a cytotoxic effect on human granulocytes, we measured lactate dehydrogenase (LDH) ${ }^{1}$ activity in toxin-exposed granulocytes as indicator of membrane damage. Granulocytes $\left(2.5 \times 10^{6}\right.$ cells) in HBSS buffer were incubated with either purified toxin $A(100 \mu \mathrm{g} / \mathrm{ml})$ or no addition (buffer) for $30 \mathrm{~min}$ at $37^{\circ} \mathrm{C}$. Cells were then centrifuged for $10 \mathrm{~s}$ on a microcentrifuge and supernatants were collected. Cell pellets were then incubated with HBSS buffer containing $1 \%$ Triton $\mathrm{X}-100$ at $37^{\circ} \mathrm{C}$ for 5 min, recentrifuged, and supernatants were recovered.

Enzyme activity was quantitated in $0.1-\mathrm{ml}$ aliquots from both supernatants using a 50-mM pyrophosphate buffer containing $77.5 \mathrm{mM}$ lactic acid and $5.2 \mathrm{mM}$ NAD at $\mathrm{pH} 8.8$ as a substrate (23). Aliquots were added to $1.4 \mathrm{ml}$ of the reaction mixture substrate, mixed with gentle inversion, and absorbance at $340 \mathrm{~nm}$ was recorded at 30-s intervals for $12 \mathrm{~min}$ at room temperature utilizing a Beckman spectrophotometer. Results were expressed as percentage release of enzyme units per $2.5 \times 10^{6}$ granulocytes per $30 \mathrm{~min} \pm$ SEM. $1 \mathrm{U}$ of the LDH activity has been defined as an increase in absorbance of 0.001 per $\min (23)$.

\section{Results}

Effects of $C$. difficile toxins on granulocyte migration. Toxin A elicited significant migration of human granulocytes in vitro at concentrations $\geq 25 \mu \mathrm{g} / \mathrm{ml}\left(10^{-7} \mathrm{M}\right)$ (Fig. 1). At higher concentrations (100-200 $\mu \mathrm{g} / \mathrm{ml}$ ) this effect of toxin A was $>90 \%$ of the maximal effect observed with the chemotactic peptide FMLP $\left(10^{-7} \mathrm{M}\right)$. Toxin B at similar concentrations elicited an increase in chemotaxis that did not differ significantly from control values. We next performed a checkerboard analysis to differentiate between chemokinetic and chemotactic effects of toxin A. These results are summarized in Table I. As the concentration of toxin A in the lower wells was increased (vertical columns), granulocyte migration increased in a dose-dependent fashion. Reversing the gradient by adding increasing toxin A concentrations in the upper wells (horizontal rows)

1. Abbreviation used in this paper: $\mathrm{LDH}$, lactate dehydrogenase.

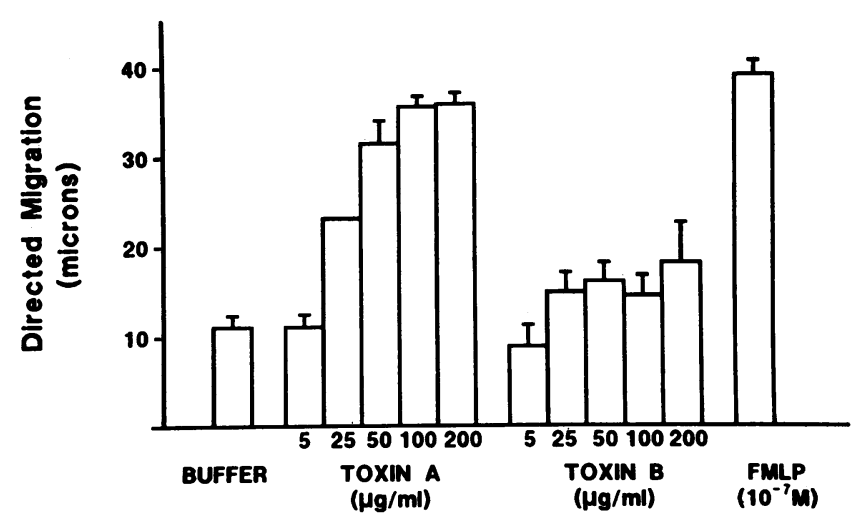

Figure 1. Granulocyte migration was measured in double-well chemotaxis chambers as described in Methods. Each bar represents the mean $( \pm \mathrm{SEM})$ migration in microns of quadruplicate assays. Concentrations of toxin A of $25 \mu \mathrm{g} / \mathrm{ml}$ or higher differed significantly from buffer $(P<0.001)$.

inhibited migration of granulocytes into the filter. These data indicate that toxin A is a chemoattractant. Exposure of granulocytes to toxin $A$ in the absence of a concentration gradient also produced a dose-dependent increase in granulocyte migration, indicating a chemokinetic response.

Effect of purified toxin on superoxide anion generation. We next examined the effect of toxin $A$ on superoxide generation by human granulocytes. Purified toxin $\mathbf{A}$ was added in final concentrations of $1-100 \mu \mathrm{g} / \mathrm{ml}$ to granulocytes and release of superoxide anion was measured. No significant differences were observed between superoxide release from toxin A-exposed, or control (buffer-exposed) granulocytes. Thus, granulocytes $\left(2 \times 10^{6}\right)$ exposed to toxin $A(100 \mu \mathrm{g} / \mathrm{ml})$ released 3.8 nmol $\mathrm{O}_{2}^{-} / 15 \mathrm{~min}$, whereas control granulocytes released 2.5 nmol $\mathrm{O}_{2}^{-} / 15 \mathrm{~min}$ (mean of four separate incubations, $P>0.1$ vs. control). Similar doses of toxin B had no significant effect on superoxide production by granulocytes under the same conditions (not shown). It has been shown that cytochalasin B greatly enhances secretion of superoxide in granulocytes stimulated with the chemotactic factor FMLP $(24,25)$. We therefore examined the effect of toxin A on superoxide generation by human granulocytes preincubated with $5 \mu \mathrm{g} / \mathrm{ml}$ of cytochalasin B for $5 \mathrm{~min}$ at $37^{\circ} \mathrm{C}$. Again no significant differences were noticed between superoxide release from toxin A-exposed vs. control (buffer-exposed) granulocytes under these experimental conditions. Granulocytes preincubated with cytochalasin $B$ and then exposed to toxin $A(100 \mu \mathrm{g} / \mathrm{ml})$ released $4.0 \mathrm{nmol} \mathrm{O}_{2}^{-} / 15 \mathrm{~min}$, whereas control granulocytes released $2.38 \mathrm{nmol} \mathrm{O}-1 / 15 \mathrm{~min}$ (mean of four separate incubations for each group, $P>0.1$ vs. control). In contrast, granulocytes exposed to FMLP $\left(10^{-6} \mathrm{M}\right)$ released $11.76 \mathrm{nmol} \mathrm{O}-1 / 15 \mathrm{~min}$ in the absence of cytochalasin $\mathrm{B}$, and $48.04 \mathrm{nmol} \mathrm{O}_{2}^{-} / 15 \mathrm{~min}$ in the presence of cytochalasin B.

Effect of toxin A on quin 2 fluorescence. Because activation of granulocytes by many stimuli is accompanied by a rapid, transient rise in free cytosolic calcium concentration, we studied the effect of toxin A on the free cytosolic calcium concentration $\left[\mathrm{Ca}^{2+}\right]_{\mathrm{i}}$ in quin 2-loaded granulocytes. Addition of toxin A (60 and $30 \mu \mathrm{g} / \mathrm{ml})$ to suspensions of granulocytes induced a rapid, transient rise in cytosolic calcium as detected by 
Table I. Chemokinetic and Chemotactic Activity of Toxin A

\begin{tabular}{|c|c|c|c|c|c|}
\hline \multirow[b]{2}{*}{$\begin{array}{l}\text { Concentration of toxin A } \\
\text { in lower compartment }\end{array}$} & \multicolumn{5}{|c|}{ Concentration of toxin A in upper compartment $(\mu \mathrm{g} / \mathrm{ml})$} \\
\hline & 0 & 25 & 50 & 100 & 200 \\
\hline \multicolumn{6}{|l|}{$\mu g / m l$} \\
\hline 0 & $45.8 \pm 0.0^{*}$ & $45.2 \pm 6.1$ & $57.3 \pm 6.2$ & $64.1 \pm 4.7$ & \\
\hline 25 & $63.4 \pm 0.9$ & $47.6 \pm 3.3$ & $60.7 \pm 5.2$ & $62.0 \pm 1.0$ & $46.7 \pm 3.6$ \\
\hline 50 & $60.7 \pm 1.6$ & $57.6 \pm 4.5$ & $59.1 \pm 5.1$ & $61.1 \pm 2.0$ & $54.3 \pm 0.2$ \\
\hline 100 & $86.7 \pm 1.7$ & $57.8 \pm 5.8$ & $63.0 \pm 14.2$ & $64.0 \pm 3.1$ & $58.5 \pm 6.1$ \\
\hline 200 & $92.1 \pm 1.5$ & $69.8 \pm 5.8$ & $76.6 \pm 10.3$ & $77.3 \pm 11.2$ & $88.4 \pm 2.0$ \\
\hline
\end{tabular}

* Granulocyte migration was measured in double-well chemotaxis chambers as described in Methods. Toxin A was added in the indicated concentrations to both lower or upper wells of the chemotaxis apparatus. Migration was measured as the distance (microns) from the top of the filter to the last focal plane, which contained two granulocytes. Data represent the mean \pm SEM of four values.

quin 2 fluorescence (Fig. $2 A$ ). This effect became evident within 1-3 s after the addition of the toxin, peaked after $\sim 30$ $\mathrm{s}$, and returned to pretreatment levels after $2 \mathrm{~min}$. Addition of lower concentrations of toxin A (12 and $6 \mu \mathrm{g} / \mathrm{ml}$ ), or of equal volumes of buffer ( $50 \mathrm{mM}$ Tris, $\mathrm{pH} \mathrm{7.4),} \mathrm{had} \mathrm{no} \mathrm{effect}$ on quin 2 fluorescence (Fig. $2 \mathrm{~A}$ ). Parallel experiments were performed with the fluorescent $\mathrm{Ca}^{2+}$ probe Indo- 1 to ascertain if this more sensitive probe would detect changes in free cytosolic calcium at concentrations of toxin below $30 \mu \mathrm{g} / \mathrm{ml}$. At a toxin concentration of $15 \mu \mathrm{g} / \mathrm{ml}$ no change in either Indo- 1 or quin 2 fluorescence was noted (not shown). Therefore, all subsequent experiments were performed with quin 2 .

To determine the source of the calcium released into the cytoplasm by toxin A treatment, we performed experiments in which extracellular or both intra- and extracellular calcium were depleted before addition of $50 \mu \mathrm{g}$ toxin A (Fig. $2 \mathrm{~B}$ ). In these studies, extracellular calcium was chelated by the addition of EGTA immediately before stimulation. Addition of EGTA to suspensions of granulocytes previously loaded with quin 2 did not alter resting $\left[\mathrm{Ca}^{2+}\right]_{\mathrm{i}}$ over the time course of these experiments, nor did it have any effect on the expected increase in quin 2 fluorescence in granulocytes exposed to 50 $\mu \mathrm{g} / \mathrm{ml}$ toxin A after $1 \mathrm{~min}$ (Fig. $2 B$, panels $a$ and $b$ ).

We next depleted extra- and intracellular calcium by loading granulocytes with quin 2 in calcium-free buffer containing 1 mM EGTA. Under these conditions, the resting intracellular calcium concentration was substantially reduced, to 10-20 $\mathrm{nM}$. Addition of toxin A $(50 \mu \mathrm{g} / \mathrm{ml})$ to these cells had no effect on quin 2 fluorescence (Fig. $2 B$, panel $c$ ). Repletion of calcium by the addition of calcium chloride $(5 \mathrm{mM})$ restored the rise in intracellular-free calcium after addition of toxin $A(50 \mu \mathrm{g} / \mathrm{ml})$ (Fig. $2 B$, panel $d$ ).

We next determined if the toxin A-associated increase in quin 2 fluorescence was inhibited by pertussis toxin. This toxin causes NAD-dependent ADP-ribosylation of the $\alpha_{i}$ subunit of $G_{i}$, one of the guanine regulatory proteins in the adenylate cyclase system (10). As shown in Fig. 3, the toxin A-induced $(50 \mu \mathrm{g} / \mathrm{ml})$ rise in quin 2 fluorescence $(a)$ was completely

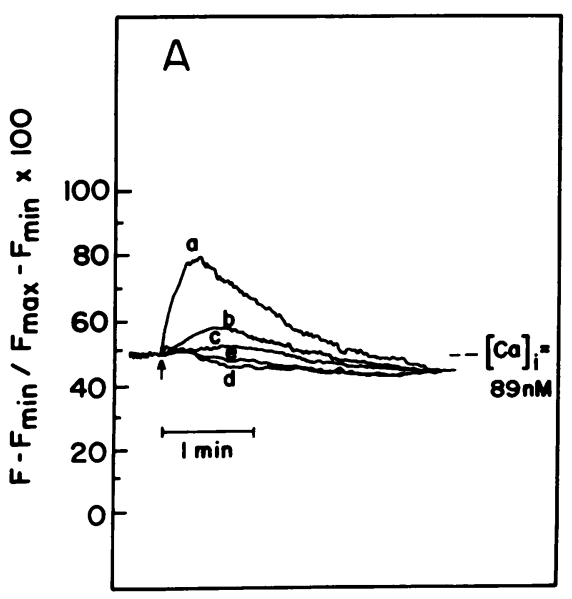

Figure 2. $(A)$ Effect of toxin $\mathrm{A}$ on $\left[\mathrm{Ca}^{2+}\right]_{\mathrm{i}}$ on quin 2 fluorescence in human granulocytes. Human granulocytes $\left(5 \times 10^{6} / \mathrm{ml}\right)$ were preloaded with quin 2 and then exposed to $60,30,12$, or $6 \mu \mathrm{g} / \mathrm{ml}$ toxin $\mathrm{A}(a, b, c$, and $d$, respectively) or $50 \mathrm{mM}$ Tris $\mathrm{HCl}$ buffer, $\mathrm{pH} 7.4$, as control $(e)$. Fluorescence at $500 \mathrm{~nm}$ was monitored continuously, and the change in fluorescent yield was calculated as described in Methods. (B) Effect of calcium depletion on toxin A-induced quin 2

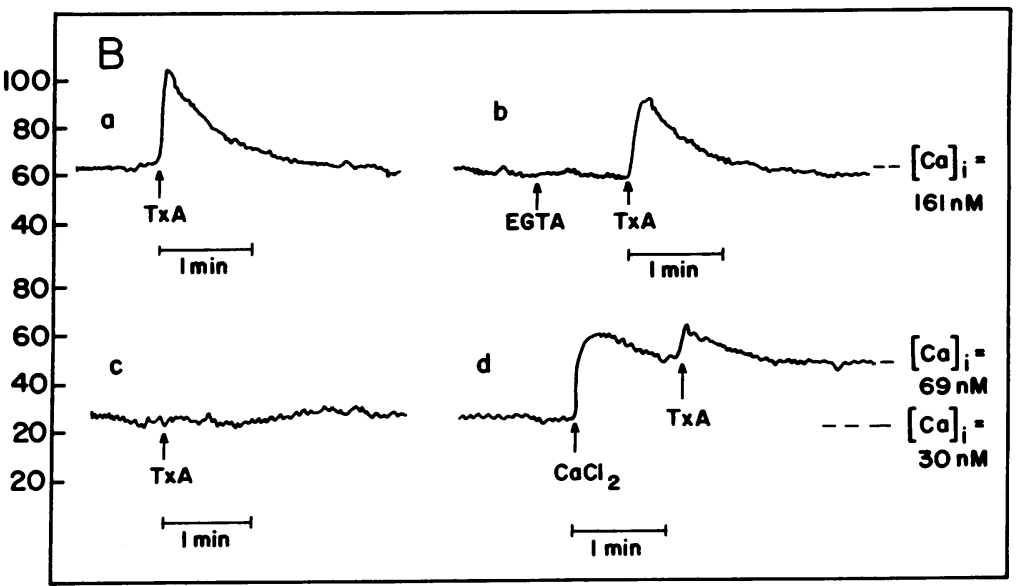

fluorescence in human granulocytes. (a) Response to $50 \mu \mathrm{g}$ toxin A. (b) Response in cells in $2 \mathrm{mM}$ EGTA to chelate extracellular calcium. (c) Response to $50 \mu \mathrm{g}$ toxin $\mathrm{A}$ in cells loaded with quin 2 in calcium-magnesium-free buffer containing 1 mM EGTA to chelate intra- and extracellular calcium. (d) Same cells as in $c$, with addition of $5 \mathrm{mM} \mathrm{CaCl}_{2}$. 


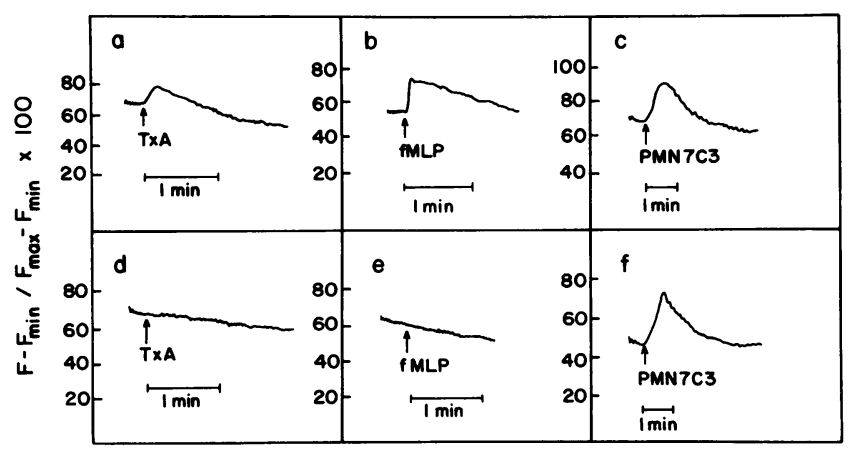

Figure 3. Effects of pertussis toxin on quin 2 fluorescence of human granulocytes exposed to toxin A, FMLP, or PMN 7C3. Human granulocytes were preloaded with quin 2 and exposed to: (a) toxin A, 50 $\mu \mathrm{g} / \mathrm{ml}$; (b) FMLP, $10^{-7} \mathrm{M}$; and (c) monoclonal anti-granulocyte antibody PMN 7C3, $50 \mu \mathrm{g} / \mathrm{ml}$. In the lower panels the granulocytes were preincubated with pertussis toxin, $500 \mathrm{ng} / \mathrm{ml}$, for $90 \mathrm{~min}$ before exposure to the same stimulants in the corresponding upper panels.

blocked by prior exposure of granulocytes to $500 \mathrm{ng} / \mathrm{ml} \mathrm{per-}$ tussis toxin for $90 \mathrm{~min}$ at $37^{\circ} \mathrm{C}(d)$. As expected (10), the FMLP-induced rise in quin 2 fluorescence was also completely blocked by prior exposure of granulocytes to pertussis toxin (e). However, pretreatment with pertussis toxin had no effect on the expected rise in quin 2 fluorescence produced by exposure of granulocytes to $50 \mu \mathrm{g} / \mathrm{ml}$ of the anti-granulocyte monoclonal antibody PMN 7C3 $(f)$, which stimulates an elevation in $\left[\mathrm{Ca}^{2+}\right]_{\mathrm{i}}$ through transduction pathways not coupled to $G_{i}$ proteins $(26,27)$.

To ascertain if the toxin effect on $\left[\mathrm{Ca}^{2+}\right]_{i}$ was secondary to nonspecific membrane damage or cellular toxicity, we measured release of the cytoplasmic enzyme LDH in toxin exposed vs. buffer-expressed granulocytes. LDH release expressed as a percent of total cellular LDH was similar in granulocytes exposed to $100 \mu \mathrm{g}$ toxin A for $30 \mathrm{~min}(2.68 \pm 0.06 \%)$ and in buffer-exposed granulocytes $(2.69 \pm 0.35 \%)$.

\section{Discussion}

We report here that highly purified toxin $\mathrm{A}$ of $C$. difficile directly activates human granulocytes in vitro, causing a rise in intracellular calcium and stimulating chemotaxis and chemokinesis.

Our results indicate that when purified $C$. difficile toxin A comes in contact with the human granulocyte surface, a rapid, dose-dependent rise occurs in the concentration of free cytosolic calcium (Fig. 2). Depletion of intracellular but not extracellular calcium diminished the rapid increase in $\left[\mathrm{Ca}^{2+}\right]_{\mathrm{i}}$ induced by toxin $\mathrm{A}$. Although our data do not define the precise mechanisms that result in the transient elevation of $\left[\mathrm{Ca}^{2+}\right]_{i}$, it appears that mobilization of intracellular calcium may be an important mediator in eliciting a chemotactic response by granulocytes to $C$. difficile toxin A. Toxin A exposure of granulocytes leads to a significant chemotactic and chemokinetic response (Fig. 1 and Table I). We speculate that human granulocytes and intestinal epithelial cells may possess membrane receptors for this toxin. For example, toxin A receptors have recently been identified on rabbit erythrocyte plasma membrane (28). By analogy with other granulocyte activators such as FMLP, when toxin A occupies its membrane receptor a complex cascade of signal transduction events ensues, includ- ing release of intracellular $\mathrm{Ca}^{2+}$. Interestingly, our results show that pretreatment of human granulocytes with pertussis toxin abolished the rise in $\left[\mathrm{Ca}^{2+}\right]_{i}$ in response to addition of toxin $\mathrm{A}$ or FMLP. It is known that treatment of human granulocytes with pertussis toxin catalyzes ADP ribosylation of the guanine nucleotide regulatory protein, $G_{i}$, and suppresses the increase in $\left[\mathrm{Ca}^{2+}\right]_{i}$ elicited by leukotriene $B_{4}$ and FMLP $(10,29)$. Our data suggest that toxin A may also mediate its effect in granulocytes via the $G_{i}$ protein.

Although toxin A causes increased intracellular calcium, and is a potent granulocyte attractant, it does not trigger release of superoxide in vitro. It is known that mobilization of intracellular calcium may modulate the rate and extent of superoxide production when granulocytes are activated by the chemotactic peptide FMLP (30). However, release of free intracellular calcium in granulocytes may not always be followed by a respiratory burst. For example, low concentrations of FMLP $\left(10^{-10}\right.$ to $\left.10^{-11} \mathrm{M}\right)$ increase intracellular calcium but do not appear to trigger a respiratory burst $(30,31)$. Similarly the antihuman granulocyte monoclonal antibody, PMN 7C3, stimulates increased $\left[\mathrm{Ca}^{2+}\right]_{\mathrm{i}}$ and cell movement without causing superoxide production $(26,32)$.

Our findings appear to be relevant to the pathophysiology of $C$. difficile enteritis, which is caused largely by toxin $\mathrm{A}$. We (33) and others (2) have reported that purified toxin A, but not $B$, elicits a profound inflammatory response in rabbit ileal loops. In our previous studies (33), instillation of purified toxin A caused secretion of protein-rich hemorrhagic fluid, increased epithelial permeability, and infiltration of the lamina propria with polymorphonuclear leukocytes and mononuclear cells. These changes have been also found to correlate with progressively increasing release of prostaglandin $E_{2}$ and leukotriene $B_{4}$ in the intestinal lumen (34). Similar concentrations of toxin B had no demonstrable effects in this in vivo model.

The in vitro experiments reported here used relatively large concentrations of toxin A. Assuming a molecular weight of $229,000, \sim 10^{-7}$ to $10^{-6} \mathrm{M}$ toxin $\mathrm{A}$ was required to elicit a quin 2 response in human granulocytes (Fig. 2). Similar amounts of toxin A (60 $\mu \mathrm{g}$ in $1 \mathrm{ml}$ buffer injected into a $10-\mathrm{cm}$ ileal loop) elicits a profound inflammatory response (33). To date, no accurate measurements are available regarding the amount or concentration of toxin A present in the stools of patients with $C$. difficile enterocolitis. The responses measured in this study were quite rapid: $<3 \mathrm{~s}$ for the intracellular calcium response and $35 \mathrm{~min}$ for chemotaxis. Although not studied by us, it is possible that much lower toxin A concentrations would have elicited positive responses in granulocytes after longer incubation periods comparable with those employed in ileal loop experiments (typically, $18 \mathrm{~h}$ ). Based on these considerations, the causal relationship between our in vitro results and $C$. difficile enterocolitis must remain speculative.

In summary, our results indicate that toxin $\mathrm{A}$ of $C$. difficile causes a transient rise in $\left[\mathrm{Ca}^{2+}\right]_{i}$ in human granulocytes, and is also a potent chemoattractant. The rise in $\left[\mathrm{Ca}^{2+}\right]_{i}$ elicited by toxin $\mathrm{A}$ appears to be mediated in part by the guanine nucleotide binding protein $G_{i}$. Taken together with observations in rabbit ileal loops $(2,33)$, our data suggest that toxin $A$ initiates infiltration of the intestinal lamina propria with granulocytes, which are then activated to release inflammatory mediators (34). These mediators in turn contribute to epithelium damage, fluid secretion, mucus release, and increased epithelial membrane permeability. 


\section{Acknowledgments}

The authors are grateful to Dr. Elizabeth Simons, Dept. of Biochemistry, Boston University School of Medicine, for her generous assistance with this project.

This study was supported by research grants AM-34583, AM-27455, and AI-21972 from National Institutes of Health. Dr. Pothoulakis is an American Gastroenterological Association/Glaxo Research Scholar.

\section{References}

1. Lyerly, D. M., D. E. Lockwood, S. H. Richardson, and T. D. Wilkins. 1982. Biological activities of toxins A and B of Clostridium difficile. Infect. Immun. 35:1147-1150.

2. Mitchell, T. J., J. M. Ketley, S. C. Haslam, J. Stephen, D. W. Burdon, D. C. A. Candy, and R. Daniel. 1986. Effect of toxins A and B of Clostridium difficile on rabbit ileum and colon. Gut. 27:78-85.

3. Taylor, N. S., G. M. Thorne, and J. G. Bartlett. 1981. Comparison of two toxins produced by Clostridium difficile. Infect. Immun. 34:1036-1043.

4. Lannroth, I., and S. Lange. 1983. Toxin A of C. difficile: production, purification and effect in mouse intestine. Acta Pathol. Microbiol. Scand. 91:395-400.

5. Schafer, D. F., W. D. Lust, B. Sircar, and N. D. Goldberg. 1970. Elevated concentration of adenosine $3^{\prime}: 5^{\prime}$-cyclic monophosphate in intestinal mucosa after treatment with cholera toxin. Proc. Nat. Acad. Sci. USA. 67:851-856.

6. Evans, D. J., Jr., L. C. Chen, G. T. Curlin, and D. G. Frans. 1972. Stimulation of adenyl cyclase by Escherichia coli enterotoxin. Nature (Lond.). 236:137-138.

7. Seligman, B. E., E. K. Gallin, D. L. Martin, W. Shain, and J. I. Gallin. 1980. Interaction of chemotactic factors with human polymorphonuclear leukocytes: studies using a membrane potential sensitive cyanine dye. J. Membr. Biol. 52:257-272.

8. Sha'afi, R. I., P. H. Naccache, T. F. P. Molski, P. Borgeat, and E. J. Goetzl. 1981. Cellular regulatory role of leukotriene $B_{4}$ : its effects on cation homeostasis in rabbit neutrophils. J. Cell Physiol. 108:401408.

9. Volpi, M., R. Yassim, W. Tao, T. F. P. Molski, P. H. Naccache, and R. I. Sha'afi. 1984. Leukotriene $B_{4}$ mobilizes calcium without the breakdown of polyphosphoinositides and the production of phosphatidic acid in neutrophils. Proc. Natl. Acad. Sci. USA. 81:5966-5971.

10. Volpi, M., P. H. Naccache, T. F. P. Molski, J. Shefcyk, C.-K. Huang, M. L. Marsh, J. Munoz, E. L. Becker, and R. I. Sha'afi. 1985. Pertussis toxin inhibits f-Met-Leu-Phe but not phorobol ester-stimulated changes in rabbit neutrophils: role of $\mathrm{G}$ proteins in excitation response coupling. Proc. Natl. Acad. Sci. USA. 82:2708-2712.

11. Pothoulakis, C., L. M. Barone, R. Ely, B. Faris, M. E. Clark, C. Franzblau, and J. T. LaMont. 1986. Purification and properties of Clostridium difficile cytotoxin B. J. Biol. Chem. 261:1316-1321.

12. Wedel, N., P. Toselli, C. Pothoulakis, B. Faris, P. Oliver, C. Franzblau, and T. LaMont. 1983. Ultrastructural effects of Clostridium difficile toxin B on smooth muscle cells and fibroblasts. Exp. Cell Res. 148:413-422.

13. Bradford, M. 1976. A rapid and sensitive method for the quantitation of microgram quantities of protein utilizing the principle of protein dye binding. Anal. Biochem. 72:248-254.

14. Sullivan, N. M., S. Pellet, and T. D. Wilkins. 1982. Purification and characterization of toxins A and B of Clostridium difficile. Infect. Immun. 35:1032-1040.

15. De, S. N., and D. N. Chatterje. 1953. An experimental study on the mechanism of action of Vibrio cholerae on the intestinal mucus membrane. J. Pathol. Bacteriol. 66:559-562.

16. Sullivan, R., D. A. Melnick, H. L. Malech, T. Meshulam, E. R. Simmons, K. G. Lazzari, P. J. Proto, A.-S. Gadenne, J. L. Leavitt, and J. D. Griffin. 1987. The effects of phorbol myristate acetate and che- motactic peptide on transmembrane potentials and cytosolic free calcium in mature granulocytes evolve sequentially as the cells differentiate. J. Biol. Chem. 262:1274-1281.

17. Melnick, D. A., T. Meshulam, A. Manto, and H. L. Malech. 1986. Activation of human neutrophils by monoclonal antibody PMN 7C3: cell movement and adhesion can be triggered independently from the respiratory burst. Blood. 67:1388-1394.

18. Zigmond, S. A., and J. G. Hirsch. 1973. Leukocyte locomotion and chemotaxis. J. Exp. Med. 137:387-392.

19. Babior, B. M., R. S. Kipnes, and J. T. Curnutte. 1973. The production by leukocytes of superoxide, a potential bacterial agent. $J$. Clin. Invest. 52:741-744.

20. Meshulam, T., P. Proto, R. D. Diamond, and D. A. Melnick. 1986. Calcium modulation and chemotactic response: divergent stimulation of neutrophil chemotaxis and cytosolic calcium response by the chemotactic peptide receptor. J. Immunol. 137:1954-1960.

21. Lazzari, K. G., P. J. Proto, and E. R. Simons. 1986. Simultaneous measurement of stimulus-induced changes in cytoplasmic $\mathrm{Ca}^{2+}$ and in membrane potential of human neutrophils. J. Biol. Chem. 261:9710-9713.

22. Pozzan, T., P. Arslan, R. Y. Tsien, and T. J. Rink. 1982. Anti-immunoglobulin, cytoplasmic free calcium, and capping in B lymphocytes. J. Cell Biol. 94:335-340.

23. Amador, E., L. E. Dorfman, and W. E. C. Wacker. 1963. Serum lactate dehydrogenase activity: an amalytical assessment of current assays. Clin. Chem. 9:391-399.

24. Becker, E. L., M. Sigman, and J. M. Oliver. 1979. Superoxide production induced in rabbit polymorphonuclear leucocytes by synthetic chemotactic peptides and A23187. The nature of the receptor and the requirement of $\mathrm{Ca}^{2+}$. Am. J. Pathol. 95:81-97.

25. Bennett, J. P., S. Cockcroft, and B. D. Gomperts. 1980. Use of cytochalasin $B$ to distinguish between early and late events in neutrophil activation. Biochim. Biophys. Acta. 601:584-591.

26. Melnick, D. A., W. M. Nauseef, S. D. Markowitz, J. P. Gardner, and H. L. Malech. 1985. Biochemical analysis and subcellular localization of a neutrophil specific antigen, PMN-7, involved in the respiratory burst. J. Immunol. 134:3346-3355.

27. Melnick, D. A., A. Manto, and T. Meshulam. 1986. Neutrophil calcium mobilization and chemotaxis can be stimulated via a guanine nucleotide binding protein independent pathway. Clin. Res. 34:526A. (Abstr.)

28. Krivan, H. C., C. F. Clark, D. F. Smith, and T. D. Wilkins. 1986. Cell surface binding site for Clostridium difficile enterotoxin: evidence for a glycoconjugate containing the sequence Gala 1-3 Gala 1-4 GlcNac. Infect. Immun. 53:573-581.

29. Goldman, D. W., F. H. Chang, L. A. Gifford, E. J. Goetzl, and H. R. Bourne. 1985. Pertussis toxin inhibition of chemotactic factorinduced calcium mobilization and function in human polymorphonuclear leukocytes. J. Exp. Med. 162:145-156.

30. Korchak, H. M., K. Vienne, L. E. Rutherford, C. Wilkenfeld, M. C. Finkelstein, and G. Weissmann. 1984. Stimulus response coupling in the human neutrophil. II. Temporal analysis of changes in cytosolic calcium and calcium efflux. J. Biol. Chem. 259:4076-4082.

31. Pozzan, T., D. Lew, C. Wollheim, and R. Y. Tsien. 1983. Is an increase in cytosolic free calcium a sufficient and necessary stimulus to trigger $\mathrm{O}_{2}$ generation and exocytosis in human neutrophils. Science (Wash. DC). 221:1413-1415.

32. Apfeldorf, M. J., D. A. Melnick, T. Meshulam, H. Rosmussen, and H. L. Malech. 1985. A transient rise in intracellular free calcium is not a sufficient stimulus for respiratory burst activation in human polymorphonuclear leukocytes. Biochem. Biophys. Res. Commun. 132:674-680.

33. Triadafilopoulos, G., C. Pothoulakis, M. J. O'Brien, and J. T. LaMont. 1987. Differential effects of Clostridium difficile toxins A and B on rabbit ileum. Gastroenterology. 93:273-279.

34. Triadafilopoulos, G., C. Pothoulakis, and J. T. LaMont. 1987. In vivo production of leukotriene $\mathrm{B}_{4}$ and prostaglandin $\mathrm{E}_{2}$ in experimental C. difficile colitis. Am. J. Gastroenterol. 82:950. (Abstr.) 